EDITORIAL

\title{
COVID-19: Formação específica em Imunoalergologia em tempos de incerteza
}

RevPort Imunoalergologia 2020;28 (2):85-86

Tiago Azenha Ramal,2

I Serviço de Imunoalergologia, Centro Hospitalar Universitário São João, Porto

${ }^{2}$ Serviço de Imunologia Básica e Clínica, Departamento de Patologia, Faculdade de Medicina, Universidade do Porto

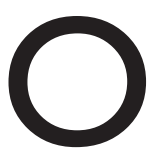
$s$ primeiros relatos de doença provocada por SARS-CoV-2, COVID-19, surgiram, ainda em dezembro de 2019, na província de Hubei, China. Foram associados ao processamento e ingestão de carne de morcego - reservatório natural para este tipo de coronavírus - em inaceitáveis condições de salubridade'. Em janeiro, não era mais do que um eco longínquo, para o qual fomos lentamente dessensibilizados pelo habitual sensacionalismo da comunicação social. Rapidamente se tornou um problema, primeiro europeu e depois nosso.

À semelhança dos seus antecessores pandémicos, severe acute respiratory syndrome coronavirus (SARS-CoV) e middle east respiratory syndrome (MERS-CoV), o SARS-CoV-2 causa pneumonia de padrão intersticial bilateral com elevada taxa de mortalidade'. A doença tem algumas particularidades interessantes. $O$ vírus invade as células humanas através da enzima conversora da angiotensina II (ECA2), que interage com a sua proteína $S$ (spike). Após incubação de 6-14 dias, a infeção pode prosseguir em 3 fases distintas. A primeira é caracterizada por uma rápida replicação viral com ativação da imunidade inata e efeito citopático. Clinicamente, manifesta-se por sintomatologia gripal-like. O reconhecimento viral inicial é desempenhado pela ativação de recetores de reconhecimento de padrões (PRR) - RIG-I-like receptors (RLR) e Toll-like receptors (TLR). Daqui resulta a libertação de interferões (IFN) de tipo I e III e de citocinas pró-inflamatórias - TNF-a, IL-I, IL-6 ${ }^{2}$. Porém, o SARS-CoV-2 é capaz de, não só escapar à deteção pelos PRR, mas também inibir a libertação de IFN. Consequentemente, pode ocorrer sobrexpressão de citocinas pró-inflamatórias e resultante desregulação da ação de macrófagos e células natural killer ${ }^{2}$. Numa segunda fase são ativadas respostas B e T, com eventual redução da carga viral. A seroconversão ocorre ao fim de 7-14 dias de infeção. Os anticorpos podem ter um papel decisivo, por exemplo, através da neutralização do domínio de ligação ao recetor da proteína S. Porém, da resposta desregulada de linfócitos Thl/Thl7 e macrófagos pode resultar a libertação maciça de citocinas, com consequente dano pulmonar e insuficiência respiratória hipoxémica. A terceira fase é caracterizada por uma tempestade citocínica, com exaustão de linfócitos T, linfopenia, hipercoagulabilidade e disfunção multiorgânica² ${ }^{2}$.

À data do primeiro diagnóstico em Portugal, 2 de março de 2020, já Itália lamentava 100 mortes, número que aumentou rápida e assustadoramente. Tornou-se 
necessário controlar a rápida disseminação do SARS-CoV-2, sendo que as instituições de saúde, a sociedade civil, as autoridades de saúde nacionais e o governo tiveram um papel muito importante.

O Centro Hospitalar Universitário de São João, que concentrou o maior número de doentes COVID-19, iniciou a rápida reestruturação do seu serviço de urgência (SU), enfermarias e unidades de cuidados intensivos, menos de uma semana após o aparecimento do primeiro caso. No sentido de promover a organização da linha da frente, composta por Internos, foi criado o Grupo de Coordenação de Internos COVID-19, do qual fazemos parte. Apesar da enorme exigência da tarefa na gestão de expectativas de colegas de diferentes especialidades, esta tem sido uma oportunidade de enriquecimento pessoal, a nível organizativo e de gestão.

A nível nacional, a maioria dos Internos de Imunoalergologia voluntariaram-se, ou foram destacados, para as mais diversas áreas: internamento COVID-19, serviço de urgência, ou acompanhamento de doentes COVID-19 em ambulatório via telefone. Todos tivemos de nos adaptar a esta nova e estranha forma de exercer Medicina, praticada dentro de um equipamento de proteção individual que quase impede a comunicação não verbal, vital para uma boa relação médico-doente, e que cria desconforto permanente. Tivemos de voltar a encarar a morte diariamente. Ainda assim, este novo dia-a-dia trouxe a cooperação com colegas de outras especialidades em equipas multidisciplinares. Trouxe valor médico-científico e humano para todos nós e ganhos em saúde para os doentes.

Entretanto, mantivemos o seguimento dos nossos doentes através de teleconsulta. Para além da habitual avaliação do controlo da patologia imunoalérgica e eventual ajuste terapêutico, fomos agentes promotores de saúde pública. Todos receamos pelos nossos doentes com imunodeficiências e pelos asmáticos. No caso da asma, a literatura mais recente tem tido um papel tranquiliza- dor $^{3,4}$, tal como Carvalho e colaboradores ${ }^{5}$ irão clarificar neste número da RPIA.

O período que atravessamos tem sido muito exigente para os Internos de Imunoalergologia. Porém, encaramos todas as nossas funções com a calma e serenidade com que encaramos, habitualmente, provocações com alergénios e imunoterapia. Fizemos a diferença em todos os locais em que fomos necessários. Entre nós, todos reconhecemos o quão valiosa foi esta experiência para a nossa formação médica, pessoal e humana. A primeira vaga de COVID-19 poderá estar em vias de ser ultrapassada. Todos temos razões para nos orgulharmos da forma eficaz como lidamos com esta ameaça, apesar de todos os constrangimentos. Em breve regressaremos à nossa atividade habitual, não com a sensação de penitência cumprida, mas de dever cumprido.

\section{Contacto:}

Tiago Azenha Rama

Serviço de Imunoalergologia

Centro Hospitalar Universitário de São João

Alameda Prof. Hernâni Monteiro

4200-319 Porto

E-mail: tarama@med.up.pt

\section{REFERÊNCIAS}

I. Zhou P, Yang XL, Wang XG, Hu B, Zhang L, Zhang W, et al. A pneumonia outbreak associated with a new coronavirus of probable bat origin. Nature 2020;579(7798):270-3.

2. Vabret N, Britton GJ, Gruber C, Hegde S, Kim J, Kuksin M, et al. Immunology of COVID-19: current state of the science. Immunity 2020; May 5 [Epub ahead of print].

3. Jackson DJ, Busse WW, Bacharier LB, Kattan M, O'Connor GT, Wood RA, et al. Association of respiratory allergy, asthma, and expression of the SARS-CoV-2 receptor ACE2 [letter]. J Allergy Clin Immunol 2020; April 26. [Epub ahead of print].

4. Jesenak M, Banovcin P, Diamant Z. COVID-19, chronic inflammatory respiratory diseases and eosinophils - Observations from reported clinical case series. Allergy 2020; May 6. [Epub ahead of print].

5. Carvalho JC, Coutinho IA, Nunes I, Moura AL, Regateiro FS. Asma e COVID-19: Atualização. Rev Port Imunoalergologia 2020;28(2): 97-109. 